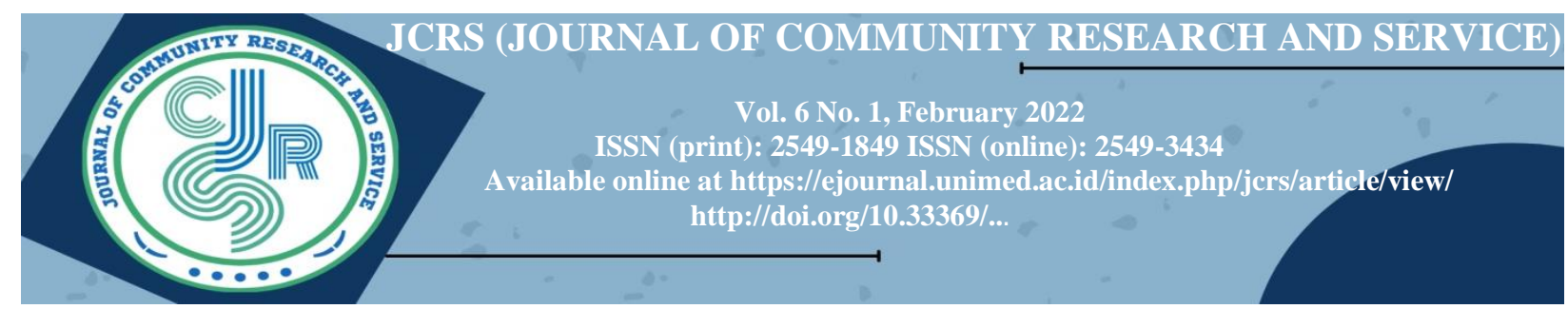

\title{
Penyuluhan Perencanaan Keuangan Sebagai Fondasi Ketahanan Keluarga Selama Pandemi COVID-19
}

\author{
Hanif Rani Iswari \\ Prodi Manajemen, Fakultas Ekonomi dan Bisnis, Universitas Widyagama Malang \\ rani@widyagama.ac.id
}

\begin{abstract}
Abstrak. Wanita dalam sebuah keluarga yakni seorang ibu memiliki peran besar selama pandemi covid-19. Pandemi Covid-19 telah berlangsung hampir 3 tahun lamanya dan berdampak signifikan terhadap ekonomi dan tatanan sosial dan selama itu wanita dalam keluarga yakni seorang ibu dituntut untuk mampu menghadapi permasalahan yang muncul walau dengan ketidaksempurnaan pengetahuan dan keterampilan. Tidak terkecuali ibu-ibu Dawis Bougenville 1 Madyopuro Kota Malang yang tinggal di Kawasan Perumahan FLPP di Kota Malang juga merasakan dampak tersebut. Pengabdian ini bertujuan untuk memberikan tambahan pengetahuan dan ketrampilan dalam lingkup perencanaan keuangan keluarga. Dilakukan dengan metode yang terbagi atas 3 tahapan dan dilaksanakan dari bulan September hingga Desember 2021. Setiap tahapan dilengkapi dengan evaluasi pre-test dan post-test. Setelah dilakukan kegiatan penyuluhan diperoleh dampak yang positif yakni meningkatnya kesadaran akan pentingnya perencanaan keuangan keluarga, meningkatnya kemampuan menyusun skala prioritas dan anggaran keuangan keluarga. Dengan adanya program ini juga mendukung ketahanan keluarga selama pendemi covid-19. Manfaat lain setelah diadakan kegiatan pengabdian ini adalah adanya kesadaran para kepala keluarga yakni suami untuk membersamai para istri (ibu) dalam mengelola keuangan keluarga serta munculnya semangat menciptakan usaha walau dengan skala kecil. Keberlangsungan program sesuai kebutuhan obyek pengabdian adalah membuat pelatihan pembukuan sederhana untuk usaha kecil yang dirintis.
\end{abstract}

Kata kunci: perencanaan keuangan, ketahanan keluarga, covid-19

Riwayat Artikel: Diterima: 22-11-2021; Direvisi: 02-12-2021; Disetujui: 23-02-2022; Tersedia online: 26-02-2022 Cara mensitasi artikel: Iswari, H.R. (2022) Penyuluhan Perencanaan Keuangan Sebagai Fondasi Ketahanan Keluarga Selama Pandemi COVID-19. Journal of Community Research and Service,6(1), xxx-xxx.

https://doi.org/10.14710/ijred.x.X.Xxx-Xxx

\section{Pendahuluan}

Wanita dalam keluarga terutama seorang ibu memiliki multi peran [1] terutama ketika pandemi covid19 yang hingga kini juga belum tuntas. Masa pandemi cukup menguruas keuangan keluarga seperti pengeluaran untuk biaya proses pembelajaran atau bekerja di rumah [1]. Lumpuhnya sektor ekonomi Indonesia dampak dari penyebaran covid-19 membuat banyak kepala keluarga terdampak dari pengurangan penghasilan hingga pemutusan kerja dan bagi mereka yang memiliki usaha dampak yang dirasa hingga harus gulung tikar, di sisi lain "dapur harus tetap ngebul" dan pengeluaran bahkan bukan semakin hemat tetapi semakin banyak keperluan karena perilaku baru, kebiasaan baru dan tuntutan baru selama masa new normal. Tekanan baru tersebut berupa risiko kesihatan fisik, psikologi hingga kehilangan pekerjaan [2] menempatkan wanita sebagai pihak yang paling rentan mengalami tekanan terutama ekonomi [3]. Peran wanita dalam keluarga terutama ibu menjadi semakin kompleks padahal tiang utama keluarga berada pada seorang wanita atau istri atau ibu [4] yang banyak dari mereka tidak dibekali cukup pengetahuan dan keterampilan untuk menghadapi dampak pandemi covid-19.

Permasalahan tersebut dialami tidak terkecuali bagi ibu-ibu Dawis Bougenville 1 Madyopuro Malang. Ibu-ibu Dawis Bougenville 1 Madopuro Kota Malang bertempat tinggal di Kawasan Perumahan Bulan Terang Utama yang berlokasi di Kelurahan Kedungkandang Kota Malang. Kelurahan Kedungkandang memiliki 15 RW (Rukun Warga) dan 108 RT (Rukun Tetangga) [5] yang di dalamnya terdapat beberapa 
kelompok PKK dan kelompok-kelompok Dawis untuk kelompok yang lebih kecil. Salah satu kelompok Dawis di RT 005 RW adalah kelompok Dawis Bougenville 1 Madyopuro Kota Malang yang berada di Kawasan Perumahan yang memperoleh Fasilitas Likuiditas Pembiayaan Perumahan (FLPP). Sesuai peruntukkannya, Perumahan Bulan Terang Utama yang merupakan perumahan FLPP ditujukan kepada Masyarakat Berpenghasilan Rendah (MBR) yang saat ini rata-rata sudah menghuni di kawasan ini sekitar 5-8 tahun [6], sehingga adapula yang telah memperoleh dampak secara ekonomi dari program subsidi pemerintah tersebut, namun tidak semua telah masyarakat lebih baik secara ekonomi terutama dalam dua tahun terakhir ketika Pandemi Covid-19 melanda. Setidaknya 60\% penghasilan keluarga menurun hingga $20 \%$ lainnya mengalami pemutusan hubungan kerja bahkan usaha gulung tikar. Menurunnya ekonomi keluarga memunculkan dampak lain bagi anggota dalam keluarga dimana emosi tidak stabil, krisis gizi, gap pembelajaran [7].

Kondisi tersebut membuat ibu-ibu Dawis Bougenville 1 Madyopuro Malang dituntut untuk mampu berperan lebih untuk mengatur keuangan keluarga untuk memenuhi kebutuhan keluarga ataupun meningkatkan ekonomi selama masa Covid-19. Saat ini telah banyak wanita dalam keluarga yakni ibu menjadi partner dalam mencari nafkah [8]. Melalui wawancara pendahuluan pada beberapa narasumber diperoleh informasi awal jika keuangan rumah tangga selama pandemi covid-19 menjadi terganggu cashflow-nya sehingga banyak dari mereka lebih berhati-hati namun karena latar belakang pengetahuan keuangan yang masih minim, mereka merasa belum cermat dalam mengelola keuangan keluarga terutama karena penurunan jumlah income atau bahkan meningkatnya pengeluaran yang tidak sebanding dengan income yang diperoleh. Dengan demikian, program pengabdian masyarakat ini menyasar permasalahan utama untuk meningkatkan literasi keuangan dengan memberikan sebuah penyuluhan tentang perencanaan keuangan bagi ibu-ibu Dawis Bougenville 1 Madyopuro Kota Malang.

Melalui program yang didesign sedemikian rupa diharapkan dalam kegiatan pengabdian masyarakat ini ibu-ibu dawis 1 bougenville Madyopuro Kota Malang dapat meningkatkan wawasan dan kemampuan menyusun rencana keuangan keluarga dan mengatur keuangan keluarga selama pandemic covid-19. Dengan upaya ini diharapkan mampu meningkatkan ketahanan keluarga selama pandemi covid-19. Keluarga yang merupakan kelompok paling kecil dalam masyarakat harus memiliki strategi untuk ketahanan keluarga menghadapi tantangan di masa pandemic covid-19 [9]. Semakin baik ketahanan keluarga, semakin baik pula kemampuan keluarga menghadapi perubahan akibat pandemi covid-19 [10] karena keluarga yang kuat secara finansial mampu memberikan dampak positif pada tatanan sosial serta ekonomi sebuah lingkungan dan Indonesia dalam lingkup yang lebih luas.

\section{Metode}

Metode program penyuluhan ini terbagi atas 3 tahapan [11] yaitu:

1. Tahap Perencanaan dan persiapan

Dalam tahapan ini, wawancara pendahuluan dilakukan untuk memastikan kembali permasalahan utama yang harus diberikan penanganan dan program penanganan yang sesuai dengan kebutuhan obyek pengabdian. Wawancara dilakukan dengan metode in depth interview yang secara tersirat menggali informasi awal perihal kondisi keuangan dan permasalahan yang dihadapi serta bentuk penanganan yang diharapkan. Melalui beberapa kali pertemuan tidak terstruktur diperoleh beberapa informasi konkret mengenai perilaku keuangan masing-masing anggota keluarga obyek pengabdian.

\section{Tahap Pelaksanaan}

Berdasarkan tahapan sebelumnya, disusunlah sebuah program pelaksanaan yang terdiri atas 3 tahapan kegiatan yakni: a) Pengenalan Perencanaan Keuangan, b) Evaluasi Kesehatan Keuangan, dan c) Penyusunan Anggaran. Dimana masing-masing tahapan tersebut dilengkapi dengan sebuah bentuk evaluasi awal yakni pre-test dan evaluasi akhir yakni post-test.

\section{Tahap Evaluasi}

Selain evaluasi yang dilakukan di masing-masing tahapan dalam bentuk pre-test dan psot test juga dilakukan evaluasi general perihal manfaat yang diperoleh oleh obyek pengabdian. 


\section{Hasil dan Pembahasan}

Program Pengabdian Kepada Masyarakat ini dilakukan oleh tim pelaksana Universitas WIdyagama Malang dengan obyek pengabdian yakni ibu-ibu Dawis Bougenville 1 Madyopuro Kota Malang dalam bentuk penyuluhan. Adapun pelaksanan dan hasil dari masing-masing tahapan sebagai berikut:

\subsection{Penyuluhan Pertama}

Agenda kegiatan penyuluhan pertama ini adalah menyampaikan pengetahuan mengenai pentingnya melakukan perencanaan, pemahaman tentang perencanaan keuangan dan tata cara merencanakan keuangan serta menyusun prioritas tujuan keuangan. Penyuluhan pertama ini dilakukan pada 23 Oktober 2021 diawali dengan pre-test dilakukan dengan mengajukan 15 pertanyaan sesuai dengan agenda penyuluhan pertama, dan diperoleh hasil jika tidak semua obyek pengabdian memiliki kesadaran akan pentingnya merencanaan keuangan karena dirasa pada saat ini yang dibutuhkan adalah bagaimana memenuhi tagihan-tagihan yang jatuh tempo sehingga obyek pengabdian lebih memprioritaskan untuk mencari cara untuk meningkatkan income dibanding hanya mengelola keuangan. Himpitan keuangan karena dampak pandemi covid-19 begitu dirasakan oleh obyek pengabdian, sehingga mindset yang tertanam pada obyek pengabdian cenderung berfikiran instan.

Berikut dokumentasi kegiatan penyuluhan pertama di salah satu kediaman obyek pengabdian:
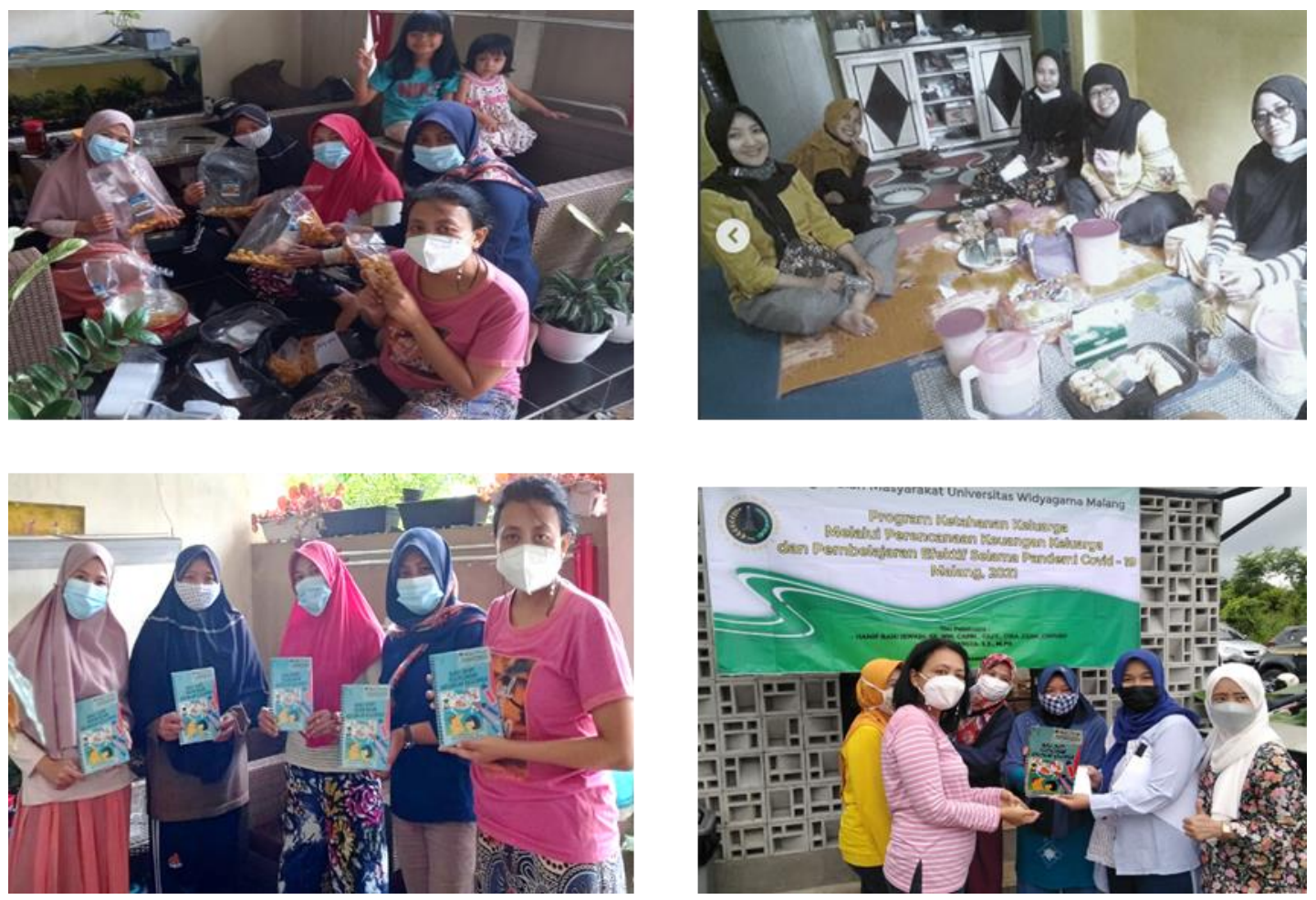

Gambar 1. Dokumentasi Kegiatan Penyuluhan Pertama tanggal 23 Oktober 2021.

Sebelum dilakukan penyuluhan, dari hasil pre-test diperoleh juga informasi perihal ketidakmampuan obyek pengabdian memiliah prioritas tujuan keuangan. Hal ini dikarenakan mereka terlalu banyak tagihan yang harus dibayarkan sehingga melupakan porsi pembagian income yang diperoleh misalnya untuk dana berjaga-jaga atau dana yang diperuntukan untuk sedekah.

Atas dasar pre-test tersebut dilakukanlah penyuluhan dengan metode pemaparan dan diskusi terbuka selama hampir 120 menit. Di dalam penyuluhan tersebut juga diberikan sebuah buku diary perencanaan keuangan yang berisikan worksheet selama diadakannya penyuluhan. Selama penyuluhan ibu-ibu dawis buegenville 1 Madyopuro mengisi dan menyusun perencanaan keuangan serta mencatat sesuai dengan kasus keuangan yang dialami dalam keluarga masing-masing. Dari kertas kerja tersebut yang merupakan bentuk visualisasi kondisi keuangan masing-masing keluarga diperoleh kesimpulan bahwa mulai adanya kesadaran akan pentingnya perencanaan keuangan serta menjadi mampu menyusun skala prioritas kebutuhan. Hal ini tercermin pada post-test yang dilaksanakan setelah kegiatan penyuluhan pertama. 
Terdapat 15 poin pertanyaan yang semua menjurus pada hasil yang menunjukkan peningkatan kesadaran dan kemampuan dalam membagi prioritas keuangan.

\subsection{Penyuluhan Kedua}

Penyuluhan yang kedua diadakan pada tanggal 20 November 2021 dan sebelum dilakukan penyuluhan diadakan pre-test dengan media berbasis game. Hasil yang diperoleh dari pre-test ini menunjukkan tingkat kesehatan keuangan obyek pengabdian dalam kondisi perlu diperhatikan karena banyak diantara obyek pengabdian memiliki tanggungan hutang online di beberapa marketplace. Dalam proses penyuluhan dengan diskusi ringan untuk mencari fakta yang memang susah untuk disampaikan yakni perihal hutang yang merupakan hal yang sensitive diperoleh fakta jika demi menutupi kebutuhan, ibu-ibu Dawis Bougenville 1 Madyopuro kota Malang menggunakan opsi pay-latter untuk membeli bahan-bahan baku guna produksi usaha kecil mereka dan karena kemampuan perhitungan HPP yang belum mumpuni seringkali belum bisa memperoleh keuntungan karena terlalu sedikit perolehan laba yang didapat setelah dikurangi pembayaran cicilan di marketplace tersebut. Berikut dokumentasi kegiatan penyuluhan dua yang diadakan di Dgunung Angkringan Malang:
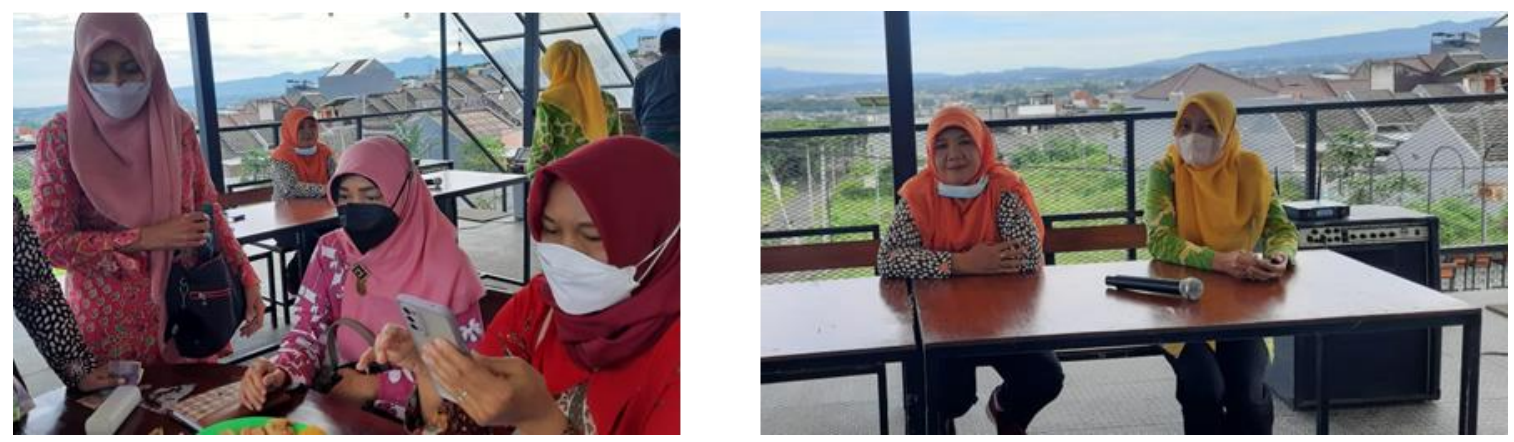

Gambar 2. Dokumentasi Kegiatan Penyuluhan Pertama tanggal 20 November 2021.

Dalam kesempatan penyuluhan kedua ini dengan agenda evaluasi kesehatan keuangan, topik berkembang dengan cukup interaktif terlebih pada topik bagaimana mengatur cash-flow usaha kecil yang mereka jalankan.

\subsection{Penyuluhan Ketiga}

Kegiatan penyuluhan yang ketiga dilaksanakan pada tanggal 27 November 2021. Agenda pada penyuluhan ketiga ini adalah menyususn anggaran perencanaan keuangan. Berikut dokumentasi kegiatan penyuluhan yang ketiga:
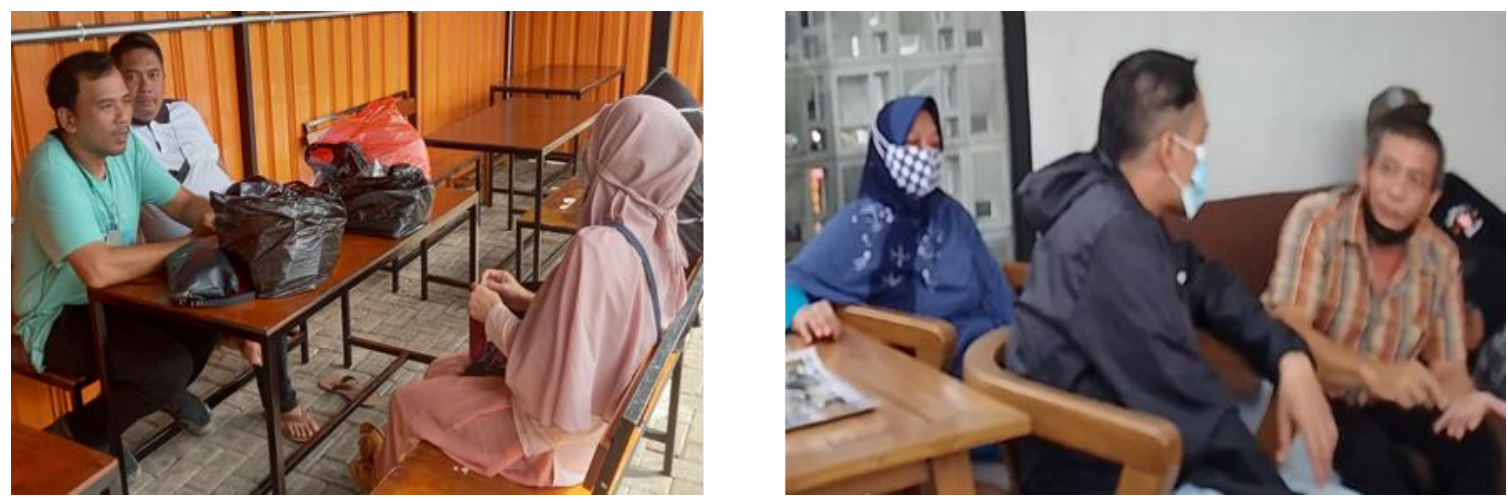

Gambar 3. Kegiatan Penyuluhan Perencanaan Keuangan Keluarga Tahap Ketiga. 

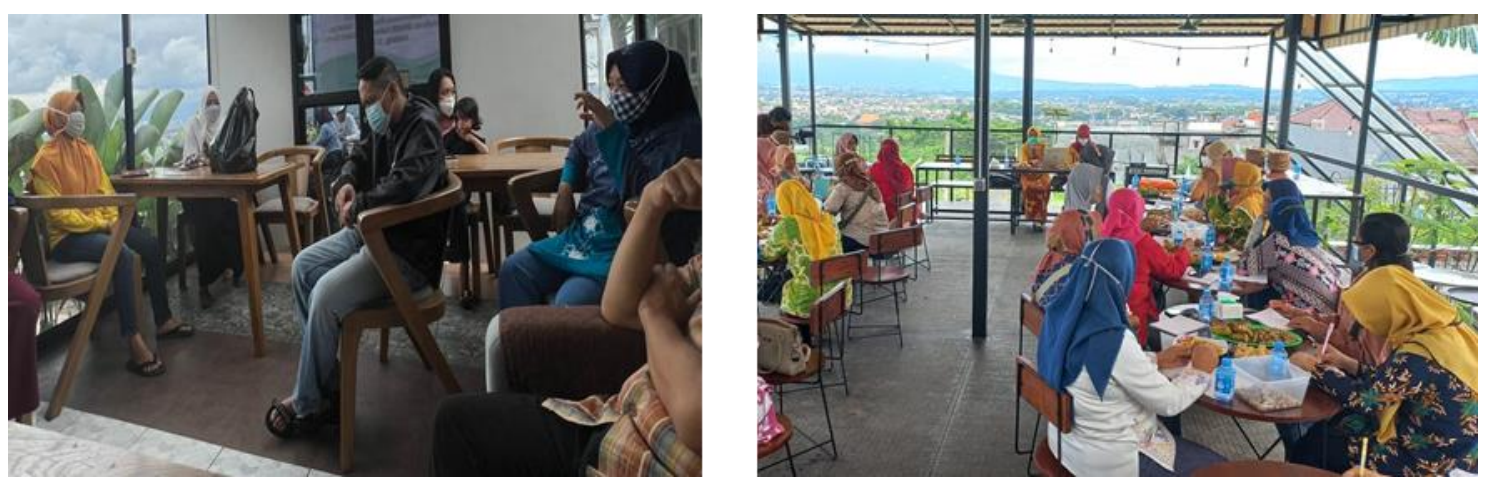

Gambar 4. Kegiatan Penyuluhan Perencanaan Keuangan Keluarga Tahap Ketiga.

Pada kesempatan kali ini, pre-test dan post dilakukan lebih terstruktur karena mengevaluasi termasuk perkembangan dari penyuluhan pertama. Adapun 30 pertanyaan yang diberikan kepada obyek pengabdian yang pada kesemptan ini didampingi oleh beberapa kepala keluarga. Hal ini dikarenakan bentuk dukungan kepala keluarga untuk membersamai para ibu dalam mengelola keuangan keluarga.

Demikian 3 kegiatan penyuluhan perencanaan keuangan yang telah berjalan lancar dan dapat diterima dengan baik oleh obyek pengabdian. Lebih lanjut untuk program pengabdian yang bisa dilaksanakan di kemudian hari adalah mendukung usaha-usaha kecil ibu-ibu Dawis Bougenville 1 Kota Malang dalam bentuk pembukuan sederhana.

\section{Kesimpulan}

Melalui kegiatan pengabdian kepada msyarakat ini dalam bentuk penyuluhan keuangan keluarga diperoleh spirit baru dalam melihat kondisi keuangan keluarga dalam masa pandemi covid-19. Di awal psikologi obyek pengabdian masih merasakan syok dan kurang kesadaran untuk merencanakan keuangan keluarga padahal pelaksanaan perencanaan keuangan keluarga mampu menguatkan ketahanan keluarga. Setelah adanya penyuluhan ini, adanya upaya para ibu Dawis Bougenville 1 Madyoupro Kota Malang dalam menyusun anggaran keuangan keluarga dan komitmen dalam pelaksanaannya, selain itu dampak diluar harapan tim pelaksana, dengan adanya program penyuluhan perencanaan keuangan mampu mendorong adanya aktivitas usaha skala kecil guna mencukupi kebutuhan saat ini. Untuk keberlangsungan program, Ibu-Ibu Dawis Bougenville 1 Madyopuro Kota Malang membutuhkan pendampingan pembukuan sederhana untuk usaha yang sedang dirintis.

Ucapan Terima Kasih. Tidak lupa kami ucapkan terimakasih kepada seluruh pihak yakni LPPM Universitas Widyagama Malang dalam fasilitas program hibah yang diberikan. Serta para peserta penyuluhan, ibu-ibu Dawis Bougenville 1 Madyopuro Kota Malang.

\section{Daftar Pustaka}

[1] Handayani R. Multi Peran Wanita Karir Pada Masa Pandemi Covid-19. J. Kaji. Gend. dan Anak. 2020; 4(1):1.

[2] Isham L, Bradbury-Jones C, Hewison A. Female family carers' experiences of violent, abusive or harmful behaviour by the older person for whom they care: A case of epistemic injustice? Sociol. Health Illn. 2020; 42(1):80 - 94.

[3] Thohari CAF, Meiningtias D. Persepsi Masyarakat Terhadap Peran Perempuan dalam Perawatan dan Peningkatan Ekonomi Keluarga di Masa Pandemi Covid-19. Marwah J. Perempuan, Agama dan Jender. 2021; 20(1):28 - 42.

[4] Boikh LI, Siregar JSM. PERAN PEREMPUAN NELAYAN PADA MASA PANDEMI COVID-19 TERHADAP PENINGKATAN EKONOMI RUMAH TANGGA PESISIR DI KELURAHAN NAMOSAIN, KECAMATAN ALAK-KOTA KUPANG. J. Geogr. 2021; 1(1):109 - 114.

[5] Primavera A. Profil Kelurahan Madyopuro, Kecamatan Kedungkandang, Kota Malang. 2016 https://ngalam.co/2016/03/25/profil-kelurahan-madyopuro-kecamatan-kedungkandang-kota-malang/

[6] Emik. Sejarah RW Jitu. 2014 https://rwjitu.or.id/sejarah/

JCRS (Journal of Community Research and Service), 6(1), 2022 
[7] Wiresti RD. Analisis dampak work from home pada anak usia dini di masa pandemi Covid-19. J. Obs. J. Pendidik. Anak Usia Dini. 2020; 5(1):641.

[8] Ilah I, Dedeh D, Patonah R, Haryati T. Peran ibu rumah tangga dalam membantu perekonomian keluarga pada masa pandemi Covid-19 di Desa Girilaya. J. Edukasi (Ekonomi, Pendidik. dan Akuntansi. 2021; 9(1):57-62.

[9] Rohaniah Y, Rahmaini R. Sosialisasi Manajemen Keuangan Keluarga pada Masa Pandemi Covid-19. ABDI MOESTOPO J. Pengabdi. Pada Masy. 2021; 4(1):45 - 49.

[10] Sunarti E. Ketahanan Keluarga Indonesia di Masa Pandemi Covid 19. Bogor: PT Penerbit IPB Press; 2021.

[11] Mulyanti D, Nurdin S. Pelatihan Perencanaan Keuangan Keluarga Bagi Ibu-Ibu PKK Kecamatan Cimenyan Kabupaten Bandung. J. Abdimas BSI J. Pengabdi. Kpd. Masy. 2018; 1(2):259 - 267. 